\title{
Selective commemoration: \\ coming to terms with German colonialism
}

\author{
Reinhart Kößler / Henning Melber
}

German colonialism lasted for three decades between 1884 and World War I. With the Treaty of Versailles in 1919, the German empire was officially declared unfit to colonise and its colonial territories were transferred by the League of Nations as trusteeships to mandatory powers. But while this was the official end of a German colonial empire, it survived in German mindsets and ambitions, further reinforced under the Nazi regime. Notwithstanding its end, the ideological impact of the colonial project on the expansionist warfare especially into Eastern Europe and the treatment of people, escalating in the Holocaust and other forms of systematic mass extermination, remained to a large extent ignored ever since. The quest for coming to terms with the violent German past focused mainly on the Third Reich.

While in West Germany, Nazi crimes were largely repressed from public discourse during the 1950s and Nazi perpetrators continued in the ranks of the state and public services, this began to change around 1960, largely due to single-handed action of persons such as state attorney Fritz Bauer who initiated the Auschwitz trial in Frankfurt, and increasingly also through insistence by a younger generation who turned towards a painful and soul-searching engagement with the dire past. Such quests for recognition of state-sponsored crimes met dogged resistance and could prevail only in a long process, in which successive groups of victims besides Jews, such as Sinti and Roma and gay people came to the fore. Claims raised in 2020 against the German railways (Möller, 2020), which had been instrumental in ferrying millions to annihilation camps, underscore that this process has by no means come to a conclusion. Still, in the eyes of the world, these efforts have received a lot of recognition, respect and earned Germany international credibility.

In keeping with this, speaking at the 75th commemoration of Victory in Europe Day (VE) in May 2020, German president Frank-Walter Steinmeier called this a day of liberation imposed by Allied military forces, including the Soviets. But as he stated, "internal liberation", the coming to terms with the heritage of dictatorship and above all the horrific mass crimes, re- 
mained "a long and painful process". ${ }^{1}$ Steinmeier's plea to "accept our historic responsibility" met broad consensus. "Internal liberation" had come some way - leaving aside comparatively weak statements by the right-wing Alternative für Deutschland (AfD). Even though this attitude and practice is viewed by many as exemplary, it has some grave shortcomings.

As noted, remembrance of Auschwitz as a substantial part of German state rationale has come about through a halting and conflicting process. For all its merits, still, by virtually singling out the Shoah (the genocide of the Jews in Europe), it marginalizes and disregards other mass crimes of the Nazi period. As recalled during the VE-Day anniversary, such elision from memory includes over 30 million victims of the war against the Soviet Union and the occupation of eastern territories in what are today Russia, Ukraine, Belorussia, Moldavia, Poland and the Baltic states. This blank spot relates to an ingrained culture in Germany of discrimination against Slavic people and to a refusal to acknowledge the crimes perpetrated by millions of ordinary German soldiers.

Another glaring lacuna concerns Germany's past as a colonial power. Despite its relatively short duration, this experience had a great impact on Germany's violent trajectory during the first half of the 20th century. Since 1945, however, this history has been largely excised from public memory. Today, many Germans are not even aware that their country once ruled colonies in Africa, Oceania, and China. Such public amnesia (Kößler \& Melber, 2018) does not imply only a lack of knowledge. Rather it is rooted in a refusal to acknowledge the practice of German colonialism and countenance the consequences.

This chapter takes up blind spots when it comes to the selective treatment of a violent German past with regard to colonialism in the current German public. While inroads have been made not least by a growing number of post-colonial initiatives and their local activities, an intimate engagement with the implications of the German colonial empire on both the people in the colonies as well as the mindsets of Germans so far remains to a large extent at the margins of a dominant culture.

1 https://www.bundespraesident.de/SharedDocs/Downloads/DE/Reden/2020/05/200 508-75-Jahre-Ende-WKII-Englisch.pdf?_blob=publicationFile. 
Historian David Andress (2018: 1) attested "cultural dementia" in the UK, France and the USA, as "particular kinds of forgetting, misremembering and mistaking the past". This goes beyond amnesia, as he argues: "In most cases, the amnesiac is aware that they do not remember; and knowledge of that lack - and of the potential to fill it from external information is something to cling to." In contrast: "The dementia sufferer is denied the comfort of knowing they don't remember" (ibid: 1.). With reference to Holocaust commemoration, Andress explicitly excludes Germany from this diagnosis. However, his characterisation of selective (or absent) memory in the three societies applies to Germany too: "They are detached from the actual history of how our societies took on their current social, economic and cultural forms; and they are wrong about where those societies fit into the world around them" (ibid: 5). Their patriotic identity "embroils people in assumptions that have visible harmful consequences for anyone outside the core of that identity, and where the collective trajectory is towards further exploitation of a historical privilege that is, as much as it is anything else, racial" (ibid: 68).

What requires clarification, however, is the use of the term dementia. Cultural dementia, as Andress insists, is irreversible. As we believe, colonial amnesia is not. It ignores existing knowledge or applies some degree of immunisation against such knowledge. But its existence provides access and can be also accessed by those who are willing to do so. In the terms of Aleida Assmann (1999: 133-140), such knowledge is not expunged from "storage memory", but still kept away from "functional memory". In this way, the existence of such knowledge, as we know, does not protect from amnesia. Authors such as Christiane Bürger (2017), less critical of the ignorance which still characterises the denialism of the ugly colonial past in German history, point out that evidence is available that, in their view, contradicts the diagnosis of amnesia. They refer to a continuous presence of the subject since the days of German colonial rule and to the accumulated knowledge about these issues. The selective, restricted, filtered or biased treatment of much of such knowledge and insights is for them a sign of aphasia - a lack of adequate language rather than a lack of memory. Lack of memory and lack of adequate language can indeed be considered as complementing mental disruptions (in our case as regards the mindset) and are not contradictory.

The existence of sufficient evidence concerning colonial atrocities and the fundamental systemic injustices with lasting structural consequences does not mean that such facts are actually taken into consideration; even 
less, that they are adequately acknowledged in the sense of being integrated in the (self-)positioning. Denialism of empirical facts as well as shunning their moral dimensions and obligations is more than aphasia. It is the (at times indeed deliberate) act of not wanting to acknowledge what could and should be known. When a staff member of the German Federal Archives (Bundesarchiv) finds it difficult - with reference to the available and meanwhile also accessible archive of the former Imperial Colonial Office (Reichskolonialamt) - to acknowledge colonial amnesia while as an archivist she is literally sitting on the documents (Herrmann, 2019: 21), such reasoning distracts from the realities in society. The mere fact that such archives and knowledge exist does not save from misperceptions or prevent denialism. In reality and despite gradual inroads and achievements by post-colonial initiatives since the turn of the century, such misconceptions are still rife and even dominant.

As Bürger (2017: 264) shows, colonial-apologetic efforts - directly or indirectly supported by institutionalized historical studies - were set to counteract and dismiss the new colonial-critical discourses that gained momentum since the late 1960s and were related to a rise in international solidarity. Bürger concludes (ibid: 276) that academic debates of the 1980s confirmed the continued existence of colonial-revisionist networks, influencing the public discourse. Such networks have not retreated or become irrelevant. These findings therefore stand in striking contrast if not in contradiction to Bürger's own steadfast dismissal of the notion of colonial amnesia, which she as well bases on the sheer existence and amount of scholarly engagement with colonialism.

Overcoming deficits caused by amnesia (or aphasia, for that matter) requires a fundamental and principled revision of perspectives, mindsets and behaviour, which would then translate into everyday practices and a common culture based on shared historical awareness, impregnating daily life as much as politics. At best, it is still a long way to get there, in a world which continues to be governed by asymmetric power relations, both globally and locally.

\section{Everyday remnants of colonial 'leftovers'}

It needs to be acknowledged that most, in particular white, Germans can afford feigning ignorance or unawareness of their country's colonial past. This is in clear contrast to descendants of the colonised who, in a country such as Namibia, have to confront the vestiges and consequences of colonialism on a daily basis. At the same time, it is a continued selective 
perspective on who Germans are, of which in particular Afro-Germans have a tale to tell - and it's not a pleasant one (Della \& Lehmann 2019).

The pitfalls of a colonial past in everyday discriminating racist language that often still transports racist stereotypes have been displayed, among others, by the continued work of Susan Arndt (Arndt, Thiel \& Walther, 2001; Arndt \& Hornscheidt, 2004; Arndt \& Ofuatey-Alazard, 2011). Such stereotypes have been internalised to an extent that they are even reproduced without any conscious intent of discrimination. Such verbal discrimination can therefore often be considered as aphasia. However, the ignorance about the context which shaped such language at the same time borders to amnesia too. Despite a growing amount of research-based scholarly insights testifying to the lasting destructive effects of the colonial-imperialist era, efforts at downplaying of German colonialism as "short-lived adventure" or "episode" (Gründer \& Hiery, 2017: 24) have survived as part of a continued dominant German perception. Such euphemisms used by the editors of a widely praised volume have not prevented further dissemination by the Federal Agency for Civic Education (Bundeszentrale für Politische Bildung) in 2018. The problematic can be clarified further by taking a look at some novels that claim to engage colonialism.

Even the best of intentions cannot always protect from a lack of sensitivity. Thus, Gerhard Seyfried (2003) - well known in the left-leaning scene for his anarchistic cartoons in the 1970s through the 1990s - drew inspiration from a visit to Namibia and as a novelist engaged the Namibian-German war of 1904 to 1908 in what was then the colony of South West Africa. His could be seen as a failed effort to emulate the pioneering novel Morenga by Uwe Timm (1978), a "benchmark for the poetics and politics of postcolonial memory in German literature", marking "the literary rediscovery of colonialism" (Göttsche, 2013: 7 and 70). In contrast, Seyfried's Herero is "an anti-Morenga that fails in its attempt to emulate his superior predecessor" (ibid: 91). It strongly reminds of romantic conceptions about European life in African colonies following the Hollywood movie Out of Africa: "Fictionalizing colonial history from a seemingly historiographical, or rather an antiquarian point of view paradoxically achieves very similar effects to reenactments of colonial life in prime-time German television features, where since the millennium docudramas have been just as popular as in literature" (ibid: 89).

This colonial gaze is reproduced in a wide panorama of (mainly female) narratives in which women share their interactions with locals if not even their experiences in "going native". Among the most prominent and successful examples in this category is 'the white Massai' by Corinne Hofmann (1998). The book turned into such a bestselling title that two more 
novels followed (Hofmann, 2003 and 2005). It also turned into a movie and the author summarised her passion for Africa in a fourth monograph (Hofmann, 2011). The implicit, not very subtle racism inherent in such narrative has been analysed by Reiniger (2008) and Maurer (2010). As observed by Göttsche (2013: 416):

"One of the modern twists in the reenactment of colonial myths ... is the shift from the male heroes of colonial novels to the female protagonists of recent works. These sometimes combine the fascination of colonial adventure in exotic terrain with the stance of a courageous anticolonialism in colonial space which gives rise to yet another myth, which is postcolonial only in the historical sense of the term, namely the myth of a 'better colonialism' (Sartre's term) which history failed to give a chance to develop."

Where in marked contrast to such romanticising clichés and the portraying of 'noble savages' the brutality of the colonial frontier society is described in drastic fiction - as in a novel that evokes the particular horrors of war in German South West Africa in all its brutality also in terms of gendered violence (Brink, 2002) - it required a new and rather small publisher even to secure a German translation (Brink, 2008). ${ }^{2}$

Given these and other gaps (if not losses) in memory or serious linguistic disorders, a supposedly ironical title such as 'No Place in the Sun' (Zimmerer, 2013) for a volume surveying 'German colonial memory places' unintentionally runs the risk to create a misleading association, which is in marked contrast to the enlightening contributions compiled. In a variety of aspects, these studies actually convey a sense of how the colonial-romantic identification has survived the loss of colonies in form of projections and desires, keeping the colonial glorification alive among subsequent generations.

\section{Revisiting colonial amnesia}

It took 110 years until the German Foreign Office acknowledged at last that the extermination strategy executed between 1904 and 1908 in then

2 Many of André Brink's novels in mainly historical colonial settings of South Africa had been published by Kiepenheuer \& Witsch. This one was considered as unsuitable for a German audience - which indeed might be a correct diagnosis as regards a public pegged to colonial amnesia. 
the German colony of South West Africa (today's Namibia) was tantamount to genocide. This long road included a resolution of the (West) German parliament in 1989 which at the dawn of Namibian independence declared, without specifying any reasons, Germany's "special responsibility" for the former colony; further, an exceptional, but in the last analysis, personal admission of guilt and a sign of remorse by the German Minister for Economic Cooperation, Heidemarie Wieczorek-Zeul at the centennial commemoration ceremony at the Waterberg in August 2004; and many evasive subsequent efforts by high-ranking representatives of the German state and government at avoiding acknowledgement of the elephant in the room when it comes to German-Namibian relations in the shadow of genocide. The turn-around occurred almost in passing at a press conference in July 2015 when a spokesperson of the Foreign Ministry responded to insistent questioning by a journalist. ${ }^{3}$

Despite such admission, an official recognition - such as the resolution adopted in 2015 by the German Parliament regarding the Armenian genocide - has not followed. Neither has the German President or the German Chancellor touched upon the subject. Both have remained tight-lipped so far, at least in their official capacities. However, the informal acknowledgement still cleared the way for bilateral negotiations that began in late 2015 between special envoys appointed by the Namibian and German governments.

At that time, a documentation compiled by the academic services of the German parliament had stated in an almost charming way (Wissenschaftliche Dienste, 2013: 4) that only to very limited degrees Germans are aware of the colonial history of the German empire in Africa and other parts of the world. ${ }^{4}$ As the paper concluded, the German colonial past in Namibia continues to remain a sensible subject, which bears some potential for excitement (Erregungspotenzial), while overall the GermanNamibian relations were graded as good (ibid.: 9). Since 2015, a total of nine meetings behind closed doors had by late 2020 not yet resulted in any official results (Melber, 2020). Reportedly, progress has been made

3 For a detailed account from the historic events until early 2017, including the build-up and aftermath to this kind of turning point, see among others Reinhart Kößler and Henning Melber (2017) and Henning Melber (2017).

4 In the original: "Grundsätzlich lässt sich feststellen, dass die koloniale Geschichte des deutschen Kaiserreiches in Afrika und anderen Teilen der Welt nur in sehr geringem Maße im Bewusstsein der Deutschen präsent ist.” Notably, the name of the author as well as several other references to sources and related information are blackened. 
and it has been claimed repeatedly that an end seems in sight. It remains in doubt, however, whether an agreement between the two governments might solve the pending matters as long as the affected communities in Namibia, who make up the majority of descendants of those who survived the genocide, will not agree. So far, such agreement is not in sight, since the Namibian government has not found a way to accommodate these concerns adequately in the negotiation process (cf. Kößler, 2020b).

Further blockages are rooted in an inadequate dealing with the postcolonial situation on the German side (cf. Kößler, 2020a). It may be said that the German special envoy in these negotiations, Rupert Polenz, stands for the predicament. There can be little doubt about the good intentions and the personal integrity of the envoy. Nevertheless, his path in the negotiations is littered with minor and more serious blunders (Kößler \& Melber, 2017: 84-94): From a purely German point of view, it may have made sense to link the original timetable of the negotiations to the German election calendar, when the election of 2017 could be expected to return a parliament clearly less amenable to the aim of reconciliation after the genocide. However, the public announcement of such issues in Namibia lent credence to concerns that the Germans were trying to call the shots. More seriously, in a meeting with members of victim communities, Polenz blew up the situation by bluntly denying any relationship between the genocide in Namibia and the Holocaust (ibid.: 87-91) - an issue that has been debated for long and also has played an important part in the reasoning of Namibian communities. Apparently, the envoy was not aware of this basic circumstance or insensitive to relevant sentiments. One of the icons of German diplomacy once stressed the need "to take your contracting partner ... seriously" and "to get a picture of the situation and of what moves this man or this woman" (Genscher, 2014: 58). Against this benchmark, German diplomacy has failed miserably in handling the intricacies of the Namibian situation during the negotiations since 2015. This is hardly because of a lack of general diplomatic skills, but rather, points to a lack of awareness related to grossly underestimating the problem at hand. One may surmise that such a slippage may have been more likely to occur in relation to Africa than, say, in transatlantic relations. ${ }^{5}$

5 In May 2021, an agreement between the Namibian and the German government was initialled that by the end of 2021, remains highly controversial, above all in Namibia. On the deficiencies of the agreement and particularly its colonialist bend, see ECCHR, 2021. 
It would be mistaken to suspect that those who drive German foreign policy were not aware of the exigencies they face. In a position paper on transitional justice of mid-2019, the Foreign Office "advocates a comprehensive understanding of confronting past injustices" (The Federal Government 2019: 8; original emphasis). It clarifies that the approach is widely defined, including "violations of economic, social and cultural rights" and "various dimensions of justice (such as retributive, distributive and restorative justice)", with transitional justice as part of social transformation processes (ibid: 8f.). As the paper argues, "in the long term, transitional justice measures help to develop inclusive cultures of remembrance" (ibid: 10; original emphasis). The authors advocate, "(p)articipative processes with a broad scope ... to ensure that transitional justice is not perceived as a project of the elites, and that the expertise and political ideas from civil-society organisations and groups (particularly those that represent victims and survivors, or have direct access to them) can be put to use" (ibid: 16; original emphasis). The paper then presents examples of transitional justice in Germany: "acknowledging and providing reparations for past injustices" (ibid: 23; original emphasis). Reference is made to "reparations and compensation for National Socialist injustices" and the paper maintains: "Given its decades-long and multifaceted experiences in this policy area, Germany can provide information about basic requirements, problems and mechanisms for the development of state and civil-society reparation efforts" (ibid.). Strikingly, however, the term colonialism (our emphasis) does not feature even once in the 32-page document. Further, the experience of the bilateral negotiations between the Namibian and the German government, dragging into their sixth year by late 2020 and apparently hinging on the issue of proper reparations, is hardly encouraging.

Still, more recently some significant shifts could be observed. When on 19 November 2020, parliament debated a whole series of motions to do with the way how to deal with the German colonial past, a remarkable consensus could be observed across all parties, with the significant exception of the right-wing $\mathrm{AfD}^{6}$. There were no longer denialist approaches toward the genocide in Namibia, or attempts to play out development cooperation against Namibian demands for reparations that had made up arguments particularly of the conservatives and liberals only a few years ago (Kößler \& Melber, 2017: 74-81). Speakers of the Left Party did critique the conservatives for a lack of consistency, but again there was almost

6 See, also for the following, Deutscher Bundestag, Plenarprotokoll 19/192, Berlin, Donnerstag, 19. November 2020, 24228 B-24241C. 
common agreement about the need to seriously address the dire colonial heritage and in particular, to earnestly look into the need for restitution of deported cultural goods now kept by German museums, which had occasioned the debate. One might consider this as a major success of years of patient and insistent work by postcolonial initiatives, mainly based in civil society (see infra); but on the other hand, a very different factor may have contributed towards this surprising unity of mind: the onslaught from the right.

Maybe it even was no coincidence that on the day before, the parliament had seen a second act of aggression in connection with demonstrations of opponents against the measures to cope with the Covid-19 pandemic. After an unsuccessful, seemingly spontaneous and failed attempt to physically storm the building in October, this time, rightist activists, with the connivance of AfD deputies, had, on occasion of another demonstration, infiltrated the building. They pestered deputies and even tried to enter offices. The outcry was treated in plenary session on the following day, but the occurrence may very well have contributed towards a closing of the ranks among the democratic parties.

Still, within the "consensus" stressed by conservative deputy Markus Koob, ${ }^{7}$ one can recognise clear differences among parties. Whereas the conservatives and the liberals, much in keeping with their former approach stressed the achievements of German policy (even though on a clearly different terrain than before), particularly the Green and the Left parties insisted on the unfinished business; they pointed to the need of a pro-active policy of remembrance including bolstering the long-term work of postcolonial initiatives, ${ }^{8}$ questioned the framework of international law, ${ }^{9}$ and called for an immediate apology not only for the genocide in Namibia but for colonial crimes more generally, along with a reconsideration of the broader framework of present day trade relations. ${ }^{10}$ Remarkably, a conservative voice stressed the need for "empathy with the victims" which ought to motivate a "dialogue" "with African states" in a spirit of true partnership. ${ }^{11}$

7 Ibid., 24229D.

8 Agnieszka Brugger (Green Party), ibid., 24229A.

9 Kathrin Vogler (Left Party), 24235A.

10 Eva-Maria Schreiber (Left Party), ibid., 24241A-B.

11 Volker Ulrich (CDU/CSU) 24242A. 
Denialism reloaded: the role of the $A f D$

As mentioned, this needs to be set against serious efforts on the Right who work towards not only a roll back, but for a very different revitalisation of colonial topics that runs directly counter to concerns about adequate remembrance and reconciliation. Such possibilities might indicate that the window of opportunity has narrowed again with right-wing populism gaining ground. Evidence is the visibility and impact of the AfD, which for some years now has secured a significant presence in the German Parliament as well as in the parliaments of the German federal states and the European Parliament. For years now it has become clear that Nazi sympathisers are wielding considerable influence in the party and have gained positions even in the highest party ranks. Thus, the new right-wing white supremacist reincarnations of megalomaniac thoughts and claims of Empire have gained serious traction in Germany.

What has been diagnosed as "cultural dementia" mainly with reference to the prevailing public mood is applicable in the changing political environment of Germany and certainly in a different vein, with regard to AfD as well.

"[...] the layering of mythology around history is not something that can be simply and uncontroversially pulled back by the application of expertise. The West's current relationship to the past is not the passive victimhood of an individual dementia sufferer, but rather an actively constructed, jealously guarded toxic refusal to engage with facts that are well-known but emotionally and politically inconvenient, and with other experiences that are devastating to the collective self-regard of huge segments of societies that have no visible desire to come to terms with reality" (Andress, 2018: 144).

Obviously, the aggressive and unashamed rebirth of colonial-apologetic propaganda runs directly counter to quests for a dialogue, seeking to find ways to address the past colonial crimes, if only as a reluctant compromise with continued flaws. Such attacks are even put forward abusing the German Parliament as a forum.

On 11 December 2019 the AfD invited for a public lecture to its chamber in the German Parliament. The event had the programmatic (sub-)title: "The balance of German colonialism. Why the Germans do not have to 
apologise and even less, to pay for the colonial era!" 12 The speaker was not some "patriotic" German, but none less than Bruce Gilley, who had managed to obtain dubious fame with an article in 2017, in which he eponymously argued "The case for colonialism." 13 In his lecture (see also Heinze, 2020), he asserted his claims to competence in the following way:

"I am not a historian, much less a historian of colonialism. I am a social scientist, and I have come to the conclusion that very little history on German colonialism meets the most basic standards of social scientific research as normally understood. It is ideological, biased, and often self-contradictory. So, my main qualification for writing about German colonial history is that I am not a historian of German colonialism" (Gilley, 2019: 1).

Having established his credentials in this way, Gilley directly moved to German South West Africa - and right away documented his profound knowledge by stating wrongly that under German rule, the territory also included "parts of present-day Botswana." As he reasoned, "unless we confront this head-on and get it right, everything we say about the rest of German colonialism will always come with the riposte "Well, what about the Herero?" (ibid.) Be aware, that his answer is not meant to be misunderstood as mis-guided satire:

"[...] let's remind ourselves that Southwest Africa was about $2 \%$ of the German colonial population (measured in terms of people-years). Just logically, imagine we conclude that Germany did a really horrible job with this $2 \%$ and a superb job with the other $98 \%$. What would our overall conclusion be about German colonialism?” (ibid).

He then, without disputing the decimation of Ovaherero by $75 \%$ and the Nama by $50 \%$ as a consequence of the German annihilation strategy, puts the blame entirely on General Lothar von Trotha as the military commander and thereby individualises the root cause of the genocide: "Germans and German policy was not genocidal: Trotha was" (ibid: 2). $\mathrm{He}$

12 In the original: "Die Bilanz des deutschen Kolonialismus. Warum sich die Deutschen nicht für die Kolonialzeit entschuldigen und erst recht nicht dafür bezahlen müssen!" (note the exclamation mark).

13 See among the numerous contributions to the debate since then for the context and in response Hira (2017). The significance of the concerted efforts personified by Gilley and a few others in terms of revisionist claims about colonialism has been highlighted by Brandon and Sarkar (2019). 
then continues with an unreserved praise song of the civilising mission to end with the appeal:

"German memory and writing on colonialism continues to suffer from a post-1918 ideological indoctrination campaign redolent of the worse aspects of totalitarianism. Having variously allied itself with totalitarian movements of the left (Soviets) and right (Nazis), this scholarly industry continues to get a free pass and to be accepted as truthful and just. It is neither. Germany's reassertion of its classical liberal and Western identity must begin with a rejection of the dogmatic and totalitarian ideology of anti-colonialism" (ibid: 6).

This reasoning coincided with an AfD draft resolution, circulated to Parliament the same day, to address the German colonial era in - as they call it - a cultural-politically differentiated fashion (Alternative für Deutschland 2019). With direct reference to a controversial statement by Günter Nooke, the Personal Representative of the German Chancellor for Africa (Heinze, 2019) the resolution claims that the German empire's colonialism contributed to liberate the African continent from archaic structures. It then recognises (following Gilley's line of argument) that the war by the German colonial troops in South West Africa led to un-proportional rigorousness and cruelties, but denies any systematic or intentional genocide by putting the blame only on von Trotha. In the context of transitional justice, such reasoning takes pride of place in devolving guilt by personalising it and attributing it to single individuals (Teitel, 2006; Galtung, 1996: 107; Galtung, 2005). In the plenary debate mentioned above, an AfD deputy even claimed, falsely, that Trotha had been punished after having been recalled because of his crimes. ${ }^{14}$ In reality, Trotha continued into late 1905 as commander in chief and governor, issued a further genocidal proclamation against Nama and received the Prussian Order of Pour le Mérite upon his return, even though he was subjected to public criticism. Such falsification clearly serves to exonerate the state which was responsible for the crimes committed under its purview.

The AfD also recognises the suffering of the victims of the colonial wars but dismisses any idea of compensation. Rather, the amount of development aid transferred since Namibia's independence is considered as impressive evidence that Germany has lived up to its historical responsibility towards a former colony. The submission therefore finds it justified to counteract the growing amnesia by means of an intensification of com-

14 Petr Bystron (AfD), Deutscher Bundestag, l.c., 24237A. 
memorative and cultural-political enlightenment. For this a federal foundation could be established to not only address German colonial history in a differentiated way (according to the understanding of the AfD), but also to transmit it accordingly. The resolution then calls on the federal government to cultivate a commemorative culture, which should bring to the fore the gainful sides of the German colonial era; to work towards a differentiated view of the time period; to promote such perspectives in the curricula for schools; to decisively oppose demands for reparations; to rebuke demands for the restitution of cultural goods from a colonial context based on the supposedly untenable classification of the colonial times as "criminal"; to appeal to communal levels in the federal states to maintain those street names which have been brought up for re-naming.

Notably, with this draft the AfD seeks to occupy the term 'amnesia', which hitherto had been applied in the opposite meaning by those critical of the colonial apologetic traits (Kössler \& Melber, 2018). In its justification for the draft resolution, it unashamedly appropriates for its own purposes studies which had a different (arguably ambiguous) intention, most prominently Bürger (2017). It attacks "cultural Marxist inspired post- and de-colonialism" and bemoans a paradigm shift since German unification, creating the impression that critical colonial-historical studies since then were all indoctrinated by and simply echoed East German ideology. The AfD blames the "left spectre" for having imposed its "normative interpretation of the past" as dominant opinion and turns those who are criticised for advocating colonial apologetic interpretations of a civilising mission into victims. The demands for restitution of cultural artefacts are disqualified as "inquisitory logic" aimed at the "removal of inalienable property" (Alternative für Deutschland. 2019: 9-11).

On 12 June 2020, the AfD tabled another draft resolution to restrict the restitution of cultural artefacts from colonial contexts (Alternative für Deutschland 2020). They deserve, as they argue, to be conserved in the cultural memory of human kind, and claim that this can only be secured under the caring and professional protection in German museums. Restitution, in contrast, would risk the loss of these objects for humanity due to neglect and is pushed due to a morally narrowing rhetoric of guilt, getting out of hand and orchestrated with regard to the colonial era. The reasoning bemoans the contamination of the entire colonial history as a crime against humanity and as a result the hyper-moralistic demands for restitution.

After giving much attention to this reactionary reasoning, one should however not throw out the baby with the bathwater: public discourse in Germany around the genocide committed in Namibia and atrocities perpe- 
trated in other parts of what was then the German colonial empire has made considerable inroads into the public sphere. This is true regarding the debate on the restitution of cultural artefacts appropriated in forms that tantamount to theft made and also with respect to deported human remains. The merit belongs decisively to a pro-active civil society. Such advances might be one of the more positive factors to explain the current colonial revisionism by right-wing populists. But then such findings may also serve as a reminder that the uphill battle is far from over.

However, revisionist thinking is not only on the offensive by right-wing extremism such as the AfD. Some writers have reversed their positions and backtracked, now to side with the those who deny genocide. Most notable among these is the renowned journalist Bartholomäus Grill, who discovered the writings of Hinrich Schneider-Waterberg, a "Southwester" farmer and hobby-historian (occupying, by the way, a farm which has been at the heartland of the Ovaherero when the Germans came and occupied by the settlers as a result of the genocide), who dismisses the genocide in German South West Africa wholesale. Grill subsequently provided him a prominent space in Germany by elevating him to the ranks of a "crown witness" ${ }^{15}$ Hardly by accident, Grill is amply referenced in the AfD resolution submitted to the German Parliament.

\section{Postcolonial initiatives making headway}

Such revisionist forays cannot obliterate the impact of a growing, if still minoritarian, postcolonial presence in the German public. Since the turn of the century, an increasing number of mostly localised initiatives have raised awareness about the colonial references in the everyday, such as street names or memorials. To this must be added a number of websites run by activists and which have changed fundamentally the choices of those who are looking for relevant information in the internet. A first visible sign of progress was the number and range of civil society activities both in Namibia and Germany that marked the $100^{\text {th }}$ anniversary of the genocide in Namibia (Zeller, 2005). In the scholarly field, several collective volumes have subsequently documented efforts to promote (self-)critical reflections on how to come to terms with an also German colonial past

15 See in detail Kößler \& Melber (2017: ch. 4), and on denialist misrepresentations Kößler (2015: ch. 5). 
(see e.g. Hobuß \& Lölke, 2007, Perraudin \& Zimmerer, 2011, BechhausGerst \& Zeller, 2018, Zimmermann \& Geißler, 2020).

In a related matter, public exchanges and even policy statements over the restitution of cultural artefacts and human remains have considerably shifted towards a more open engagement with the legacy of the criminal nature of transferring goods appropriated by use of force (Garsha, 2020). While in 2011, on occasion of a first restitution of human remains to Namibia the German government all but marginalised the event (Kößler, 2015: ch.12), the recent debate in parliament was marked by particularly conservative deputies proudly insisting on relevant achievements.

Such shifts continue to be underwritten by the work of local initiatives which has partly seeped into academia, such as in more systematic forays into local history (Grewe et al., 2019). Still, this important work still hinges on voluntary commitment and remains precarious, while the renaming of some streets, particularly in Berlin, that took their names from colonial stalwarts signals visible progress. Verbal political commitments such as the intention, proclaimed in the coalition pact for the Berlin state government in 2016, to work for memorial sites and institutions to honour the victims of colonialism and to project knowledge about German colonialism, largely remain on paper so far.

\section{An on-going struggle}

The significant inroads into the public discourse that postcolonial initiatives succeeded to make since the turn of the century are by no means secured. As we have seen, a backlash from colonial revisionism and white supremacy, combined with anti-migration xenophobia has become very visible, including on the parliamentary rostrum. As with the Black Lives Matter movement in the US, Britain or France and its attacks against racist and colonialist memorials in these countries, gains need to be actively defended and new advances cannot be taken for granted. The battles are far from over. What has been diagnosed for other states, applies for Germany too:

“[...] there are entire bookshops' worth of good historical work, whole departments of bold young historians (and some grizzled old veterans) who have been telling their students, and anyone else who would listen, how it really was for at least a generation. The problem remains what to do when people don't want to listen, or learn" (Andress, 2018: 106). 
As Mark Terkessidis (2019: 191-192) points out, it remains a challenging task to see to it that German colonialism will not be forgotten. Terkessidis sees a potential problem of mainly local postcolonial efforts in their focus on Germany's oversea colonies. This might obliterate (post)imperial history within Europe. Such a tendency risks to limit engagement with racism and coloniality to 'black communities' and to deal with colonialism as a kind of separate special subject. Terkessidis concedes that there is no clear answer as to how commemorative work should look like and which forms it should take. With reference to Young (1992) he supports the view that the best form of commemoration might be a never-ending debate about how such memory work should be pursued and to expand such discussion into the arena of the post-imperial (Terkessidis, 2019: 199p.).

German memory politics and practices are not quite as exemplary as much of German mainstream public discourse would like to make us believe. In fact, the engagement with the violent past particularly of the first half of the 20th century is an ongoing and painful as well as conflictual process. Inasmuch as this process has been seen to consecutively encompass crimes and victim groups that had been silenced before, such an observation can only underline the magnitude of the task. "Internal liberation”, as a goal stated in President Steinmeier's VE Day speech, remains hard work on a long road ahead. It means conflict and pain, and it must never end.

\section{References}

Alternative für Deutschland (2019): Antrag, Die deutsche Kolonialzeit kulturpolitisch differenziert aufarbeiten, Deutscher Bundestag, 19. Wahlperiode, Drucksache 19/15784, 11 December 2019, https://dipbt.bundestag.de/dip21/btd/19/157 /1915784.pdf (23.11.2020).

Alternative für Deutschland (2020): Antrag, Restitution von Sammlungsgut aus kolonialem Kontext stoppen. Deutscher Bundestag, 19. Wahlperiode. Drucksache 19/19914, 12 June 2020, https:/dip21.bundestag.de/dip21/btd/19/199/1919 914.pdf (22.11.2020).

Andress, David (2018): Cultural Dementia. How the West has Lost its History, and Risks Losing Everything Else. London: Head of Zeus.

Arndt, Susan \& Hornscheidt, Antje (2004): Afrika und die deutsche Sprache. Ein kritisches Nachschlagewerk. Münster: Unrast.

Arndt, Susan \& Ofuatey-Alazard, Nadja (2011): Wie Rassismus aus Wörtern spricht. (K)Erben des Kolonialismus im Wissensarchiv deutscher Sprache. Münster: Unrast. 
Arndt, Susan, Thiel, Heiko \& Walther, Ralf (2001): AfrikaBilder. Studien zu Rassismus in Deutschland. Münster: Unrast.

Assmann, Aleida (1999): Erinnerungsräume. Formen und Wandlungen des kulturellen Gedächtnisses. München: C.H.Beck.

Bechhaus-Gerst, Marianne \& Zeller, Joachim (Es.) (2018): Deutschland Postkolonial? Die Gegenwart der imperialen Vergangenheit. Berlin: Metropol.

Brandon, Pepjin \& Sarkar, Aditya (2019): Labour History and the Case against Colonialism. In: International Review of Social History, 64 (1), 73-109.

Brink, André (2002): The Other Side of Silence. London: Secker \& Warburg.

Brink, André (2008): Die andere Seite der Stille. Berlin: Osburg.

Bürger, Christiane (2017): Deutsche Kolonialgeschichte(n). Der Genozid in Namibia und die Geschichtsschreibung der DDR und BRD. Bielefeld: transcript.

Della, Tahir \& Lehmann, Bebero (2019): Afrodeutsche und eine deutsche Afrikapolitik. Zwischen kritischer Aufarbeitung und kolonialen Kontinuitäten. In: Melber, Henning (Ed.): Deutschland und Afrika - Anatomie eines komplexen Verhältnisses. Frankfurt/Main: Brandes \& Apsel, 197-208.

European Centre for Constitutional and Human Toghtd (ECCHR) (2021): The "reconciliation agreement" - a lost opportunity. https://www.ecchr.eu/fileadmin/ Hintergrundberichte/ECCHR_GER_NAM_Statement.pdf (1.11.2021).

Galtung, Johan (1996): Peace by Peaceful Means: Peace and Conflict, Development and Civilization. London: Thousand Oaks.

Galtung, Johan (2005): Twelve creative ways to foster reconciliation after violence. In: Intervention, 3 (3), 222-234.

Garsha, Jeremiah J. (2020): Expanding Vergangenheitsbewältigung? German Repatriation of Colonial Artefacts and Human Remains. In: Journal of Genocide Research, 22 (1), 46-61.

Genscher, Hans-Dietrich (2014): Germany's role in Namibia's independence. In: Bösl, Anton, du Pisani, André \& Zaire, Dennis U. (Eds): Namibia's Foreign Relations. Historic contexts, current dimensions, and perspectives for the $21^{\text {st }}$ Century. Windhoek: Macmillan Education Namibia, 51-58.

Gilley, Bruce (2019): The Case for German Colonialism. Paper presented in the German Parliament on 11 December 2019. https://www.researchgate.net/public ation/338555799_The_Case_for_German_Colonialism (21.11.2020).

Göttsche, Dirk (2013): Remembering Africa. The Rediscovery of Colonialism in Contemporary German Literature. Rochester: Camden House.

Grewe, Bernd-Stefan et al. (2018): Freiburg und der Kolonialismus. Vom Kaiserreich zum Nationalsozialismus. Freiburg i.B.: Stadtarchiv.

Gründer, Horst \& Thierry, Hermann Joseph (2017): Die Deutschen und ihre Kolonien.Ein Überblick. Berlin: be.bra.

Heinze, Robert (2019): A technocratic reformulation of colonialism, Africa is a country, 21 January 2019, https://africasacountry.com/2019/01/a-technocratic-ref ormulation-of-colonialism (21.11.2020). 
Heinze, Robert (2020): Colonial Revisionism in Germany, Africa is a Country, 22 January 2020, https://africasacountry.com/2020/01/colonial-revisionism-in-germ any (21.11.2020).

Herrmann, Sabine (2019): Koloniale Amnesie? - 100 Jahre Archiv zur Geschichte der deutschen Kolonien. Archive zur Kolonialgeschichte, 18 June 2019 https://w ww.bundesarchiv.de/DE/Content/Publikationen/Aufsaetze/aufsatz-s-herrmann-k oloniale-amnesie.pdf?_blob=publicationFile (22.11.2020).

Hira, Sandew (2017): A decolonial critique of the racist case for colonialism, Decolonial International Network, 22 September 2017, https:/din.today/wp-content/ uploads/2017/09/The-Racist-case-for-colonialism.pdf (22.11.2020).

Hobuß, Steffi \& Lölke, Ulrich (2007): Erinnern verhandeln. Kolonialismus im kollektiven Gedächtnis Afrikas und Europas. Münster: Westfälisches Dampfboot.

Hofmann, Corinne (1998): Die weiße Massai. München: A1.

Hofmann, Corinne (2003): Zurück aus Afrika. München: A1.

Hofmann, Corinne (2005): Wiedersehen in Barsaloi. München: A1.

Hofmann, Corinne (2011): Afrika meine Passion. München: A1.

Kößler, Reinhart (2015): Namibia and Germany. Negotiating the Past. Windhoek: University of Namibia Press and Münster: Westfälisches Dampfboot.

Kößler, Reinhart (2019): Zwischen kolonialer Amnesie und konstruktivem Engagement. Postkoloniale Asymmetrien. In: Melber, Henning (Ed.): Deutschland und Afrika - Anatomie eines komplexen Verhältnisses. Frankfurt/Main: Brandes \& Apsel, 187-196.

Kößler, Reinhart (2020a): Postcolonial asymmetry: Coping with the consequences of genocide between Namibia and Germany. In: Albrecht, Monika (Ed.): Postcolonialism Cross-Examined. Multi-Directional Perspectives on Imperial and Colonial Pasts and the Neocolonial Present. Abingdon: Routledge, 117-134.

Kößler, Reinhart (2020b): Diversität und Erinnerung: Zur Auseinandersetzung um die Konsequenzen des kolonialen Völkermordes (1904-1908) in Namibia. In: Bogner, Artur et al. (Eds.): Die Welt aus der Perspektive der Entwicklungssoziologie. Baden-Baden: Nomos, 165-186.

Kößler, Reinhart \& Melber, Henning (2017): Völkermord - und was dann? Die Politik deutsch-namibischer Vergangenheitsbearbeitung. Frankfurt/Main: Brandes \& Apsel.

Kößler, Reinhart \& Melber, Henning (2018): Koloniale Amnesie. Zum Umgang mit der deutschen Kolonialvergangenheit. Standpunkte 9/2018. Berlin: Rosa Luxemburg Stiftung.

Maurer, Elke Regina (2010): Fremdes im Blick, am Ort des Eigenen. Eine Rezeptionsanalyse von “Die weiße Massai”. Herbolzheim: Centaurus.

Melber, Henning (2017): Genocide Matters. Negotiating a Namibian-German Past in the Present. In: Stichproben. Vienna Journal of African Studies, no. 33, 1-24.

Melber, Henning (2019): Das deutsche Afrika. In: ibid. (Ed.), Deutschland und Afrika - Anatomie eines komplexen Verhältnisses. Frankfurt/Main: Brandes \& Apsel, 7-21. 
Melber, Henning (2020): Germany and Namibia: Negotiating Genocide. In: Journal of Genocide Research, 22 (4), 502-514.

Möller, Tobias (2020): Weil die Züge ihn nie losließen. Entschädigung für Holocaustüberlebende, taz, 21.10.2020 https://taz.de/Entschaedigung-fuer-Holocaust ueberlebende/!5721216\&s=Westerbork/ (21.11.2020)

Perraudin, Michael \& Zimmerer, Jürgen with Katy Heady (2011): German Colonialism and National Identity. New York/London: Routledge.

Reiniger, Franziska (2008): Die große Liebe in einer fremden Welt. Die Inszenierungen von Schwarzsein und Weißsein in gegenwärtigen Afrikaromanen am Beispiel Corinne Hofmanns "Die weiße Massai". Saarbrücken: VDM Verlag.

Teitel, Ruti (2006): The Transitional Apology. In: Barkan, Elazar \& Karn, Alexander (Eds.): Taking Wrongs Seriously. Apologies and Reconciliation. Stanford: Stanford University Press, 101-114.

Terkessidis, Mark (2019): Wessen Erinnerung zählt? Koloniale Vergangenheit und Rassismus heute. Hamburg: Hoffmann und Campe.

The Federal Government (2019): Interministerial Strategy to Support "Dealing with the Past and Reconciliation (Transitional Justice)" in the Context of Preventing Crises, Resolving Conflicts and Building Peace. Berlin: German Federal Foreign Office.

Wissenschaftliche Dienste (2013): Deutscher Bundestag, Dokumentation. Zur kolonialen Vergangenheit Deutschlands in Namibia. Geschichte - Erinnerungskultur - Aufarbeitung. Deutscher Bundestag 2013 https://www.bunde stag.de/resource/blob/405272/fc16f05eb5fea3b4da9ece62b7c3abef/wd-1-069-13-p df-data.pdf (21.11.2020).

Young, James E. (1992): The Counter-Monument: Memory Against Itself in Germany Today. In: Critical Inquiry, 18 (2), 267-296.

Zeller, Joachim (2005): Genozid und Gedenken. Ein dokumentarischer Überblick. In: Melber, Henning (Ed.): Genozid und Gedenken. Namibisch-deutsche Geschichte und Gegenwat. Frankfurt/Main: Brandes \& Apsel, 163-188.

Zeller, Joachim (2019): Weg vom Vergessen? (Post)Koloniale Erinnerungskultur in Deutschland. In: Melber, Henning (Ed.): Deutschland und Afrika - Anatomie eines komplexen Verhältnisses. Frankfurt/Main: Brandes \& Apsel, 173-185.

Zimmerer, Jürgen (2013): “Kein Platz an der Sonne". Erinnerungsorte der deutschen Kolonialgeschichte. Frankfurt/Main: Campus.

Zimmermann, Olaf \& Geißler, Theo (2019): Kolonialismus-Debatte: Bestandsaufnahme und Konsequenzen. Berlin: Deutscher Kulturrat. 